\title{
Detailed Review of Cloud based Mobile application for the stroke patient
}

\author{
Balagopal Ramdurai \\ Masters of Business Administration- ITM \\ Dubai- United Arab Emirates
}

\begin{abstract}
In the current years, due to the significant developments in technologies in almost every domain, the standard of living has been improved. Emergence of latest innovations, advanced machinery and equipment especially in the healthcare domain, have simplified the diagonalizing process to a wide extent. Smart techniques employed in medical applications resolved the detection and rectification of various diseases. This work reviews the cloud based mobile application for stroke patients. The prime goal of this research is to study the challenges and necessary measures to be implemented for the rehabilitation of patients on post-stroke. Furthermore, the existing cloud-based services and the techniques to be modified for the improvement in the patients' health status need to be explored.
\end{abstract}

Keywords: stroke, cloud computing, healthcare, mobile application.

\section{INTRODUCTION}

In recent years, due to the rapid advancements in technologies, there has been a lot of improvement in the medical sector. Lots of innovations in the medical sciences have led to the emergence of advanced machinery and equipment simplifying the process to a huge extent. In spite of the advances in the healthcare sector, the problem of figuring out the root cause of newly emerging diseases is still persisting (Lou et. al., 2017). However, the trending techniques like cloud computing, block chain. artificial intelligence etc. employed in the healthcare sector, have resolved this issue to a certain extent. Research for the detection and diagnosis of several diseases is progressing in the medical sector.

Stroke is a chronic disease and is considered to be the major cause of the public health crisis. The population of stroke patients has been rising every year and the death rate is also growing simultaneously. It has been estimated by researchers that someone dies every 4 mins, due to stroke (Zhou et. al., 2018). In the current scenario, stroke is considered to be the eminent source of adult disability. People diagnosed with stroke either suffer with prolonged disability or get affected by cognitive, physical, social functioning. Hence optimal rehabilitation is important in this regard (Munich et. al., 2017). The stroke patients need to be practically and emotionally strengthened for health improvement. Additionally, awareness of social isolation risk is very essential among rehabilitation experts (Karaca et. al., 2019). About $11.13 \%$ of deaths are said to have occurred due to stroke and is considered to be the second largest source of death. Due to the advancements in mobile healthcare, there has been huge improvement in patient care leading to patient's health status.

\section{A. Cloud based services:}

With rapid technology advancement cloud becomes an important pillar for any solution. The application for improvising patient care needs to be stored in the cloud for scalability and complete availability with security. The data is used for reading and analysing the pattern in stroke patients for improving recovery rates.

\section{a) Medical Distributed Utilization of Services \& Applications (MEDUSA)}

This technique is based on a cloud platform. It is capable of advanced medical data processing, quick information exchange, smart decision making, remote collaboration etc. As a result, it simplifies the process of acquiring and retrieval of medical data through its advanced features. This platform is highly beneficial in the healthcare sector. Data monitoring of stroke patients and the necessary measures to be implemented for rehabilitation can be easily achieved through this platform (Barros et al., 2015).

\section{b) Clinical Performance Monitoring Application (CPMA)}

The prime motive of this application was to monitor the clinical data of stroke patients for rehabilitation. The application was designed using three phases. The phases comprised modelling, implementation and evaluation. Modelling phase involved identifying the goals, defining the clinical metrics for the analysis, determining the data resources. Implementation phase involved configuring applications, application reports and mapping the clinical data to the reporting database. In the evaluation phase, feedback obtained from user experiences were analysed by the technical and medical experts for implementing suitable measures 
for further improvement in healthcare (Mata et. al., 2016).

\section{REVIEW OF EXISTING STUDIES}

Cao et al., (2015) proposed a technique for reducing the stroke through fog computing. The proposed UFall technique performed better in terms of sensitivity and specificity. About $75 \%$ of specificity and $88 \%$ of sensitivity were achieved. The proposed algorithm was implemented using cost-effective devices. However, the need for further improvement in specificity was illustrated. The requirement of huge datasets pertaining to biomedical applications and their experimentation for enhancing the systems' efficacy were highlighted. Further investigation regarding the implementation of the proposed algorithm in the realtime applications is required.

Seoet. al., (2015) proposed a technique for validating the effectiveness of mobile application in determining the vascular threats in stroke patients. The analysis was conducted using clinical data of 6 months. The study revealed that dyslipidaemias, hypertension and diabetes were the basis of anticipation of stroke in patients. The approach was successful in testing the potentiality of the mobile application. However, the proposed technique was unable to determine the outcomes of drug adjustment. For the analysis, data of people with only 20-80 years of age were collected and neurologically deficient patients were excluded in the study. Complications in the data registration process of users was the main drawback of this approach.

Andrew et. al., (2017) proposed a mobile application for analysing the clinical metrics and its effects in stroke patients. About 4953 cases were used for the study. From the results, it was inferred that out of 4953 cases, 1173 cases were considered as erroneous entries and 1190 cases for inclusion criteria. Real-time data collected through smartphones were highly beneficial in analysing acute strokes. It was estimated that about $9.7 \%$ of age-related cases and $7.4 \%$ of sex related cases were missing during the data analysis. Usage of huge sample size enhanced the effectiveness of the study. However, the inability of the technique to address the endovascular intervention issues was considered to be the drawback of this study.

Richardson et al., (2019) conducted a survey of wearables for stroke by acquiring data without the intervention of the user. Feedbacks were produced by the application of data mining techniques. For the analysis, data was collected from the public sources. Videos of patients diagnosed with Aphasia/Dysarthria were used as datasets. The dataset included 16 patients diagnosed with stroke of which 8 were categorised as Aphasia and remaining were categorized as
Dysarthria. The desired speech samples were extracted from the videos and the irrelevant speech samples were eliminated. For the experimental purpose, data was split into 4 test sets and 4 even sets. The proposed technique was successful in classifying the speech samples for stroke. This study indicated the feasibility of using speech samples in the unconstrained area. However, further research in analysing the walking and typing data acquired from sensors needs to be addressed.

Piranet. al., (2019) designed mobile applications for analysing the performance of stroke patients. The study used 18 exclusion criteria for the research. Results estimated that among 30,132 applications, $2.7 \%$ were considered to be highly beneficial and $8.7 \%$ were modelled for caregivers and survivors of stroke. The applications designed were successful in providing the visual attention and language therapy, estimation of stroke risk, patients communication, rehabilitation, identification of acute stroke and atrial fibrillation services. About 769 applications were designed for detecting other diseases. The proposed scheme effectively solved the problems pertaining to communication and language. However, the study reviewed only Apple iTunes applications excluding the reminder application pertaining to medication. Sleep apnoea risk factors were not considered included for the analysis.

Hodaet. al., (2015) proposed a technique for rehabilitation of patients diagnosed with stroke and their recovery on post-stroke. To improve the motor functions of patients on post-stroke was the prime aim of this work. Analysis was conducted using the data of 45 healthy people and 3 people diagnosed with stroke. Kinematic patterns of patients diagnosed with stroke and healthy people were compared using Dynamic time warping and optical alignment methods. Recovery performance of patients on post-stroke were analysed using AutoRegressive Integrated Moving Average model (ARIMA). Performance of ten weeks was estimated by computing the four sessions average. But analysis used only the first eight weeks of data and the last 2 weeks data for forecasting. Testing the Jerkiness in the curves demonstrated the patients' upper limb instability. Post rehabilitation, feedback regarding the patients' experience were collected for further improvement. On evaluating the feedback, it was noted that the proposed technique satisfied the patients to a huge extent.

Further, assessment of patients' health status was simplified due to the updated information provided by the system based on feedback. Improvement in the upper limbs movement and control during the training period were demonstrated in the results. The approach was successful in testing the patients. For patient numbered 1 and 3 an error lesser than $2.0 \%$ 
was achieved and $10.35 \%$ was achieved for patient number 3. Rehabilitation performance was effectively studied using DTW algorithm. High precision rate was achieved in the recovery process of patients using ARIMA. However, the need for analysis with a large number of patients should be addressed. Furthermore, analysis needs to be conducted using different kinematic variables for accuracy enhancement.

III. COMPARATIVE ANALYSIS

\begin{tabular}{|c|c|c|c|c|c|}
\hline Refs & Objectives & Applications & Techniques & $\begin{array}{l}\text { Obtained results / } \\
\text { Merits }\end{array}$ & Demerits \\
\hline $\begin{array}{l}\text { Ali et al., } \\
(2018)\end{array}$ & $\begin{array}{l}\text { To describe } \\
\text { thescope,effect } \\
\mathrm{s} \text {, challenges } \\
\text { and } \\
\text { applications of } \\
\text { cloud } \\
\text { computing in } \\
\text { the medical } \\
\text { sector. }\end{array}$ & $\begin{array}{l}\text { Healthcare } \\
\text { applications }\end{array}$ & Cloud computing & $\begin{array}{l}\text { The various } \\
\text { challenges, } \\
\text { advantages and } \\
\text { applications in the } \\
\text { healthcare sector } \\
\text { were illustrated. } \\
\text { The research can be } \\
\text { highly beneficial for } \\
\text { developing new } \\
\text { technologies in } \\
\text { future. }\end{array}$ & $\begin{array}{l}\text { The need for } \\
\text { further research } \\
\text { pertaining to the } \\
\text { privacy of patient } \\
\text { data was } \\
\text { illustrated. } \\
\text { The techniques } \\
\text { for proper } \\
\text { decision making } \\
\text { based on the } \\
\text { updated data } \\
\text { needs to be } \\
\text { proposed. }\end{array}$ \\
\hline $\begin{array}{l}\text { García et al., } \\
\text { (2019) }\end{array}$ & $\begin{array}{l}\text { To monitor and } \\
\text { determine the } \\
\text { cerebral stroke } \\
\text { through cloud } \\
\text { technique. }\end{array}$ & $\begin{array}{l}\text { Healthcare } \\
\text { sector }\end{array}$ & $\begin{array}{l}\text { Android studio } \\
\text { developmen-t, } \\
\text { Android API } 26 \\
\text { SDK }\end{array}$ & $\begin{array}{l}\text { Results concluded } \\
\text { that among } 90 \text { tests, } \\
\text { accurate results were } \\
\text { obtained from } 16 \\
\text { tests and } 74 \text { tests } \\
\text { performed } \\
\text { inaccurately. } \\
\text { About } 239,496 \mathrm{~ms} \\
\text { of time was required } \\
\text { for conducting the } \\
\text { complete test. } \\
\text { The proposed } \\
\text { technique was } \\
\text { successful in } \\
\text { detecting the } \\
\text { symptoms of stroke. }\end{array}$ & $\begin{array}{l}\text { Further research } \\
\text { in detecting and } \\
\text { analyzing the } \\
\text { symptoms of } \\
\text { distinct diseases } \\
\text { were illustrated. }\end{array}$ \\
\hline $\begin{array}{l}\text { Chang et al., } \\
\text { (2018) }\end{array}$ & $\begin{array}{l}\text { To develop an } \\
\text { application } \\
\text { based on } \\
\text { mobile phones } \\
\text { for determining } \\
\text { the efficiency } \\
\text { of self- } \\
\text { assessmen-t for } \\
\text { patients } \\
\text { diagnosed with } \\
\text { stroke. }\end{array}$ & $\begin{array}{l}\text { Healthcare } \\
\text { sector }\end{array}$ & $\begin{array}{l}\text { modified Rankin } \\
\text { scale (mRS), } \\
\text { activities of daily } \\
\text { living (ADL) } \\
\text { scale, Epidata } \\
\text { 3.1, Chi-square }\end{array}$ & $\begin{array}{l}\text { Results estimated } \\
\text { that out of } 50 \\
\text { patients, } 49 \text { were } \\
\text { diagnosed with } \\
\text { ischemic stroke and } \\
\text { one with } \\
\text { hemorrhagic stroke } \\
96.8 \% \text { of sensitivity } \\
\text { and } 82 \% \text { of } \\
\text { specificity were } \\
\text { achieved. }\end{array}$ & $\begin{array}{l}\text { Further analysis } \\
\text { using large } \\
\text { sample size needs } \\
\text { to be undertaken. }\end{array}$ \\
\hline
\end{tabular}




\begin{tabular}{|c|c|c|c|c|c|}
\hline & & & & $\begin{array}{l}\text { mRS achieved a } \\
0.718 \text { kappa value. }\end{array}$ & \\
\hline $\begin{array}{l}\text { Requenaet al., } \\
\text { (2019) }\end{array}$ & $\begin{array}{l}\text { To develop a } \\
\text { mobile } \\
\text { application for } \\
\text { creating an } \\
\text { awareness for } \\
\text { adopting } \\
\text { hygienic } \\
\text { lifestyle, } \\
\text { simplifying the } \\
\text { communicatio- } \\
\text { n process with } \\
\text { healthcare } \\
\text { members. }\end{array}$ & $\begin{array}{l}\text { Healthcare } \\
\text { applications }\end{array}$ & $\begin{array}{l}\text { Android, version } \\
17.0 \text { software, } \\
\text { Fisher exact test, } \\
\text { Mann-Whitney U } \\
\text { test }\end{array}$ & $\begin{array}{l}\text { Results concluded } \\
\text { that } 67.3 \% \text { of } \\
\text { patients were } \\
\text { categorized under } \\
\text { FARMALARM } \\
\text { group and } 32.7 \% \\
\text { patients under } \\
\text { control group. } \\
\text { It was estimated that } \\
\text { the control group } \\
\text { had higher levels of } \\
\text { hemoglobin A1c } \\
\text { (HbA1c) plasma. } \\
\text { FARMALARM } \\
\text { group contained a } \\
\text { lower level of total } \\
\text { cholesterol. } \\
\text { Higher vascular } \\
\text { threats in the } \\
\text { FARMALARM } \\
\text { group. } \\
\text { The FARMALARM } \\
\text { was feasible in } \\
\text { creating stroke } \\
\text { awareness. }\end{array}$ & $\begin{array}{l}\text { Inability in } \\
\text { randomly } \\
\text { organizing the } \\
\text { subjects. } \\
\text { Lack of measures } \\
\text { taken for } \\
\text { prevention of } \\
\text { stroke. } \\
\text { Limited } \\
\text { knowledge on } \\
\text { smart phones } \\
\text { usage in elderly } \\
\text { people. }\end{array}$ \\
\hline $\begin{array}{l}\text { Fell et al., } \\
\text { (2019) }\end{array}$ & $\begin{array}{l}\text { To develop } \\
\text { low-cost } \\
\text { equipment for } \\
\text { monitoring the } \\
\text { data of } \\
\text { caregivers, } \\
\text { healthcare staff } \\
\text { and patients } \\
\text { using mobile } \\
\text { technology. }\end{array}$ & Telemedicine & $\begin{array}{l}\text { Functional Reach } \\
\text { Test (FRT), } 10 \\
\text { Meter Walk Test } \\
(10 \mathrm{MWT})\end{array}$ & $\begin{array}{l}\text { Proposed technique } \\
\text { was successful in } \\
\text { analyzing the data of } \\
33 \text { people. } \\
\text { The 10MWT } \\
\text { technique performed } \\
\text { better in terms of } \\
\text { clinician scores. The } \\
\text { scores were } \\
\text { estimated based on } \\
\text { Spearman Rho } \\
\text { coefficient. }\end{array}$ & $\begin{array}{l}\text { Inefficiency in } \\
\text { acquiring the data } \\
\text { of two people out } \\
\text { of } 35 \text {. }\end{array}$ \\
\hline $\begin{array}{l}\text { Grau- } \\
\text { Pelliceret al., } \\
(2019)\end{array}$ & $\begin{array}{l}\text { To determine } \\
\text { the gait speed } \\
\text { in patients } \\
\text { diagnosed with } \\
\text { stroke. }\end{array}$ & Medical domain & 10MWT & $\begin{array}{l}\text { Walking speed of } \\
\text { patients diagnosed } \\
\text { with stroke was } \\
\text { effectively } \\
\text { estimated. } \\
\text { Effects of } \\
\text { Multimodal } \\
\text { Rehabilitation } \\
\text { Programs were } \\
\text { studied. }\end{array}$ & $\begin{array}{l}\text { Further analysis } \\
\text { using large data } \\
\text { size needs to be } \\
\text { performed. } \\
\text { Limited data was } \\
\text { used for analysis. } \\
\text { Assessment of } \\
\text { data and follow- } \\
\text { up needs to be } \\
\text { done on a } \\
\text { quarterly basis. }\end{array}$ \\
\hline $\begin{array}{l}\text { Gross et al., } \\
(2017)\end{array}$ & $\begin{array}{l}\text { To simplify the } \\
\text { walking of } \\
\text { stroke patients } \\
\text { using a mobile } \\
\text { robot. }\end{array}$ & $\begin{array}{l}\text { Healthcare } \\
\text { domain }\end{array}$ & Robotics & $\begin{array}{l}\text { During } \\
\text { rehabilitation, } \\
\text { cognitive,menta-1 } \\
\text { and walking } \\
\text { impairments were } \\
\text { resolved. } \\
\text { Robotic training was } \\
\text { highly beneficial in } \\
\text { training the patients. } \\
\text { The effectiveness of } \\
\text { walking in stroke } \\
\text { patients was }\end{array}$ & $\begin{array}{l}\text { Inability of } \\
\text { proposed work in } \\
\text { providing the } \\
\text { training due } \\
\text { issues relating to } \\
\text { liability and } \\
\text { elevator } \\
\text { regulations. } \\
\text { Techniques for } \\
\text { providing the } \\
\text { training on } \\
\text { different floors in }\end{array}$ \\
\hline
\end{tabular}




\begin{tabular}{|c|c|c|c|c|c|}
\hline & & & & demonstrated. & $\begin{array}{l}\text { a building need } \\
\text { to be proposed. } \\
\text { Implementation } \\
\text { of a robotic } \\
\text { trainer in medical } \\
\text { practice needs to } \\
\text { be investigated. }\end{array}$ \\
\hline $\begin{array}{l}\text { Martins et al., } \\
\text { (2019) }\end{array}$ & $\begin{array}{l}\text { To evaluate the } \\
\text { mobile } \\
\text { application in } \\
\text { the stroke } \\
\text { treatment. }\end{array}$ & Medical domain & $\begin{array}{l}\text { Android } \\
\text { technique }\end{array}$ & $\begin{array}{l}\text { Cost-effective and } \\
\text { simple } \\
\text { implementation. } \\
\text { The application } \\
\text { developed was } \\
\text { successful in } \\
\text { analyzing the } \\
\text { performance of } \\
\text { patients diagnosed } \\
\text { with acute stroke. } \\
\text { The technique } \\
\text { simplified the } \\
\text { physicians decision } \\
\text { making process. }\end{array}$ & $\begin{array}{l}\text { Improvement in } \\
\text { telestroke } \\
\text { applications. } \\
\text { Analyzing the } \\
\text { performance } \\
\text { using imaging } \\
\text { modalities. }\end{array}$ \\
\hline $\begin{array}{l}\text { Wantakaet al., } \\
\text { (2019) }\end{array}$ & $\begin{array}{l}\text { To model a } \\
\text { technique for } \\
\text { managing } \\
\text { stroke patients. }\end{array}$ & Medical sector & $\begin{array}{l}\text { FAST track } \\
\text { method }\end{array}$ & $\begin{array}{l}\text { FAST track } \\
\text { technique } \\
\text { successfully } \\
\text { developed and } \\
\text { managed the } \\
\text { performance of } \\
\text { patients diagnosed } \\
\text { with stroke. }\end{array}$ & $\begin{array}{l}\text { Effectiveness of } \\
\text { the system needs } \\
\text { to be improved } \\
\text { further. }\end{array}$ \\
\hline $\begin{array}{l}\text { Sureshkum- } \\
\text { aret al., (2015) }\end{array}$ & $\begin{array}{l}\text { To design a } \\
\text { web application } \\
\text { for controlling } \\
\text { the disabilities } \\
\text { of patients on } \\
\text { post-stroke. }\end{array}$ & $\begin{array}{l}\text { Healthcare } \\
\text { domain }\end{array}$ & Web application & $\begin{array}{l}\text { Cost-effective } \\
\text { technique. } \\
\text { Highly benefited the } \\
\text { stroke survivors and } \\
\text { caregivers during } \\
\text { their rehabilitation. } \\
\text { Simplified the data } \\
\text { accessing process } \\
\text { for experts and } \\
\text { medical staff. } \\
\text { Feasible due to the } \\
\text { handheld and } \\
\text { portability features } \\
\text { of cell phones. } \\
\text { Content is easily } \\
\text { accessible through } \\
\text { laptops, tablets etc. }\end{array}$ & $\begin{array}{l}\text { Further analysis } \\
\text { using a large } \\
\text { number of } \\
\text { patients needs to } \\
\text { be performed. }\end{array}$ \\
\hline $\begin{array}{l}\text { Kato et al., } \\
\text { (2016) }\end{array}$ & $\begin{array}{l}\text { To model a } \\
\text { tele- } \\
\text { rehabilitation } \\
\text { system for } \\
\text { patients on } \\
\text { post-stroke. } \\
\text { To improve the } \\
\text { movement of } \\
\text { patients during } \\
\text { the } \\
\text { rehabilitation } \\
\text { process. }\end{array}$ & $\begin{array}{l}\text { Healthcare } \\
\text { sector }\end{array}$ & Kinect & $\begin{array}{l}\text { Improvement in the } \\
\text { patients movement, } \\
\text { performance time } \\
\text { was noted. } \\
\text { Patient movements } \\
\text { were tracked using } \\
\text { 3D images. }\end{array}$ & $\begin{array}{l}\text { Automatic } \\
\text { feedback } \\
\text { detection } \\
\text { techniques need } \\
\text { to be proposed by } \\
\text { analyzing the } \\
\text { performance. }\end{array}$ \\
\hline Sureshkum- & To determine & Healthcare & Web application & Improvements in the & Limited data was \\
\hline
\end{tabular}




\begin{tabular}{|l|l|l|l|l|l|}
\hline aret al., (2016) & $\begin{array}{l}\text { the feasibility } \\
\text { of the proposed } \\
\text { web } \\
\text { application. } \\
\text { To figure-out } \\
\text { the challenges } \\
\text { encountered by } \\
\text { the participants. }\end{array}$ & domain & & $\begin{array}{l}\text { clarity of images } \\
\text { and videos were } \\
\text { achieved. } \\
\text { Operational } \\
\text { difficulties } \\
\text { encountered during } \\
\text { the intervention } \\
\text { were resolved. }\end{array}$ & used for analysis. \\
\hline $\begin{array}{l}\text { Hossain et al., } \\
(2018)\end{array}$ & $\begin{array}{l}\text { To develop a } \\
\text { technique } \\
\text { based on cloud } \\
\text { for } \\
\text { rehabilitation } \\
\text { of patients } \\
\text { post-stroke. }\end{array}$ & Medical domain & $\begin{array}{l}\text { Cloud computing, } \\
\text { Augmented } \\
\text { Reality }\end{array}$ & $\begin{array}{l}\text { Patients gestures, } \\
\text { rehabilitation } \\
\text { exercises were } \\
\text { identified } \\
\text { effectively. } \\
\text { Improvement in the } \\
\text { patients recovery } \\
\text { process was } \\
\text { observed. }\end{array}$ & $\begin{array}{l}\text { Multi-sensor-y } \\
\text { techniques for } \\
\text { handling huge } \\
\text { data needs to be } \\
\text { proposed. } \\
\text { Analysis needs to } \\
\text { be conducted for } \\
\text { a large number of } \\
\text { patients. } \\
\text { Techniques for } \\
\text { determining } \\
\text { patients' stress } \\
\text { levels needs to be } \\
\text { designed. }\end{array}$ \\
\hline
\end{tabular}

\section{CONCLUSION}

The cloud-based services employed for the healthcare domain, especially for stroke patients were reviewed. This paper discussed the existing services provided by the healthcare sector including patients who have suffered stroke. The mobile applications based on cloud for overcoming the challenges in rehabilitation period on post-stroke were explored. Further, the necessity of modification in the existing techniques for analysing the performance of stroke patients using huge data samples need to be studied. Additionally, awareness programs for educating people about the stroke effects needs to be conducted. Techniques for proper decision making after analysing the symptoms prestroke and protecting the privacy of data need to be developed. For better utilization of services based on smartphones by elderly people, training programs pertaining to the usage of smartphones and latest techniques embedded in the modern devices employed in the healthcare domain needs to be conducted.

\section{V.SUGGESTION}

Telemedicine and Telehealth applications aid the doctors and patients through unified communications and hence connect people and data via the cloud. Through these applications, all stroke victims are seen by an on-call neurosurgeon through video conferencing. Mobile devices or computers are employed for accessing cloud-based technology by the doctor. 'Telestroke' an application could be used for examining the stroke patients and for conducting the entire assessment. The doctor can review radiology results and consult with other professionals as well, all via unified communications.

\section{ACKNOWLEDGMENT}

The heading of the Acknowledgment section and the References section must not be numbered.

\section{REFERENCES}

[1] Lou, S., Carstensen, K., Jørgensen, C.R. and Nielsen, C.P., 2017. 'Stroke patients' and informal carers' experiences with life after stroke: An overview of qualitative systematic reviews". Disability and rehabilitation, 39(3), pp.301-313.

[2] Zhou, X., Du, M. and Zhou, L., 2018. "Use of mobile applications in post-stroke rehabilitation: a systematic review". Topics in stroke rehabilitation, 25(7), pp.489-499.

[3] Karaca, Y., Moonis, M., Zhang, Y.D. and Gezgez, C., 2019. "Mobile cloud computing based stroke healthcare system". International Journal of Information Management, 45, pp.250-261.

[4] Barros, R. S., Borst, J., Kleynenberg, S., Badr, C., Ganji, R. R., de Bliek, H., .. \&Olabarriaga, S. D. (2015, September). "Remote collaboration, decision support, and on-demand medical image analysis for acute stroke care". In European Conference on Service-Oriented and Cloud Computing (pp. 214-225). Springer, Cham.

[5] Cao, Y., Chen, S., Hou, P. and Brown, D., 2015, August. "FAST: A fog computing assisted distributed analytics system to monitor fall for stroke mitigation". In 2015 IEEE International Conference on Networking, Architecture and Storage (NAS) (pp. 2-11). IEEE

[6] Seo, W.K., Kang, J., Jeon, M., Lee, K., Lee, S., Kim, J.H., Oh, K. and Koh, S.B., 2015. "Feasibility of using a mobile application for the monitoring and management of stroke-associated risk factors". Journal of Clinical Neurology, 11(2), pp.142-148.

[7] Ali, O., Shrestha, A., Soar, J. and Wamba, S.F., 2018. "Cloud computing-enabled healthcare opportunities, issues, and applications: A systematic review". International Journal of Information Management, 43, pp.146-158. 
[8] Author, "An Efficient and Time Saving Web Service Based Android Application" SSRG International Journal of Computer Science and Engineering 2.8 (2015): 18-21.

[9] Andrew, B.Y., Stack, C.M., Yang, J.P. and Dodds, J.A., 2017. mStroke:"Mobile Stroke"-Improving Acute Stroke Care with Smartphone Technology. Journal of Stroke and Cerebrovascular Diseases, 26(7), pp.1449-1456.

[10] Mata, P., Kuziemsky, C. E., \& Peyton, L. (2016). "A Development Methodology for a Stroke Rehabilitation Monitoring Application". In HEALTHINF (pp. 400-405).

[11] Richardson, A., Ari, S. B., Sinai, M., Atsmon, A., Conley, E. S., Gat, Y., \&Segev, G. (2019). "Mobile Applications for Stroke: A Survey and a Speech Classification Approach". ICT4AWE, page to appear.

[12] García, L., Tomás, J., Parra, L., \&Lloret, J. (2019). “An mhealth application for cerebral stroke detection and monitoring using cloud services". International Journal of Information Management, 45, 319-327.

[13] Chang, H., Zhao, J., Qiao, Y., Yao, H., Wang, X., Li, J. and Liu, J., 2018. "Mobile phone application for selfassessment of acute stroke patients: A tool for extended care and follow-up". Medicine, 97(26).

[14] Requena, M., Montiel, E., Baladas, M., Muchada, M., Boned, S., López, R., ... \&Pagola, J. (2019). "Farmalarm: Application for Mobile Devices Improves Risk Factor Control After Stroke". Stroke, 50(7), 1819-1824.

[15] Piran, P., Thomas, J., Kunnakkat, S., Pandey, A., Gilles, N., Weingast, S., .. \& Levine, S. R. (2019). "Medical Mobile Applications for Stroke Survivors and Caregivers". Journal of Stroke and Cerebrovascular Diseases, 28(11), 104318.

[16] Fell, N., True, H. H., Allen, B., Harris, A., Cho, J., Hu, Z., ... \&Salstrand, R. (2019). "Functional measurement poststroke via mobile application and body-worn sensor technology". mHealth, 5 .

[17] Grau-Pellicer, M., Chamorro-Lusar, A., "MedinaCasanovas, J., \&Serdà Ferrer, B. C. (2019). Walking speed as a predictor of community mobility and quality of life after stroke". Topics in stroke rehabilitation, 26(5), 349-358.

[18] Gross, H. M., Meyer, S., Scheidig, A., Eisenbach, M. Mueller, S., Trinh, T. Q., ... \& Fricke, C. (2017, May) "Mobile robot companion for walking training of stroke patients in clinical post-stroke rehabilitation". In 2017 IEEE International Conference on Robotics and Automation (ICRA) (pp. 1028-1035). IEEE.

[19] Hoda, M., Hoda, Y., Hage, A., Alelaiwi, A., \& El Saddik, A. (2015). "Cloud-based rehabilitation and recovery prediction system for stroke patients". Cluster Computing, 18(2), 803-815

[20] Martins, S. C., Weiss, G., Almeida, A. G., Brondani, R. Carbonera, L. A., de Souza, A. C., ... \& Sousa, F. B. (2019). "Validation of a Smartphone Application in the Evaluation and Treatment of Acute Stroke in a Comprehensive Stroke Center". Stroke, STROKEAHA119.

[21] Wantaka, C., Kitidumrongsuk, P., Soontornpipit, P., \&Sillabutra, J. (2018, March)."Design and Development of Data Model for Stroke FAST Track System". In 2018 International Electrical Engineering Congress (iEECON) (pp. 1-4). IEEE

[22] Sureshkumar, K., Murthy, G.V.S., Munuswamy, S., Goenka, S. and Kuper, H., 2015. 'Care for Stroke', a web-based, smartphone-enabled educational intervention for management of physical disabilities following stroke: feasibility in the Indian context. BMJ innovations", 1(3), pp.127-136.

[23] M.Sasi and Dr.L.Larance, "Analysis and Design of Mobile Cloud Computing for Online Banking Application System" SSRG International Journal of Mobile Computing and Application 1.1 (2014): 16-19.

[24] Kato, N., Tanaka, T., Sugihara, S., Shimizu, K., \& Kudo, N. (2016). "Trial operation of a cloud service-based threedimensional virtual reality tele-rehabilitation system for stroke patients". In 2016 11th International Conference on
Computer Science \& Education (ICCSE) (pp. 285-290). IEEE.

[25] Sureshkumar, K., Murthy, G.V.S., Natarajan, S., Naveen, C., Goenka, S. and Kuper, H., (2016). "Evaluation of the feasibility and acceptability of the 'Care for Stroke Intervention in India, a smartphone-enabled, carersupported, educational intervention for management of disability following stroke". BMJ open, 6(2), p.e009243.

[26] Hossain, M. S., Hoda, M., Muhammad, G., Almogren, A., \&Alamri, A. (2018). "Cloud-supported framework for patients in post-stroke disability rehabilitation". Telematics and Informatics, 35(4), 826-836.

[27] Munich, S.A., Tan, L.A., Nogueira, D.M., Keigher, K.M., Chen, M., Crowley, R.W., Conners, J.J. and Lopes, D.K., 2017. "Mobile real-time tracking of acute stroke patients and instant", secure inter-team communication-the Join app. Neurointervention, 12(2), p.69. 